\title{
Ecosystem services of recreational parks in downtown Łódź (Central Poland)
}

\author{
Andrzej Długoński \\ Cardinal Stefan Wyszyński University, Faculty of Biology and Environmental Sciences, \\ Department of Environmental Engineering, Wóycickiego 1/3 St, 01-938 Warszawa, Poland, \\ e-mail: a.dlugonski@uksw.edu.pl
}

Received: 31 October 2017/Accepted: 5 February 2018

\begin{abstract}
Ecosystem services (ES) are the benefits that society and economy derive from the environment through natural processes of ecosystems. Urban ecosystems contribute to public health and improve the quality of life of urban residents and should be taken into account when making decisions on sustainable urban development and revitalization. Recreational parks are very important components of green urban infrastructure. The aim of the study was to define the types and subtypes of ecosystem services in nine recreational parks located in the downtown zone of Łódź, Poland, using my own classification scheme (a case study). The research shows the diversification of ES depending on the park, and suggests that the potential of parks is currently not fully used. The planned revitalization of downtown Łódź could extend the range of ecosystem services.
\end{abstract}

Key words: ecosystem, services offered to the public, green areas, big city.

\section{Introduction}

Ecosystem is a multifunctional community of living organisms interacting with each other and their environment. According to the 2005 Millennium Ecosystem Assessment [MEA], ecosystem services are "the benefits people obtain from ecosystems"(MEA, 2005). In general, these include provisioning services (i.e. food, fresh water, wood and fiber fuel), regulating services (i.e. climate regulation, flood regulation, water purification), cultural services (i.e. aesthetic, spiritual, educational), and supporting services (i.e. nutrient cycling, soil formation, primary production). This short list of four ecosystem service types were developed within TEEB (The Economics of Ecosystems and Biodiversity) project, is recommended by the European Union and widely used (TEEB, 2010, 2012). Above mentioned four types are then divided in several subtypes. Classifications found in scientific literature on ecosystem ser- vices are not completely unified and oft adapted to the studied ecosystem(s) (Costanza et al., 1997; Baur et. al., 2014; Deptuła, 2014; Speak et al., 2015; Singh \& Singh, 2017).

Despite a numerous of publications on ecosystem services on a global scale (Szulczewska, 2014; Żylicz, 2015; Kronenberg \& Hubacek, 2016), relatively few of them concern urban case studies (Haase et al., 2014; Speak et al., 2015; Czembrowski \& Kronenberg, 2016; Kabisch et al., 2016) and show actual and detailed data regarding individual urban ecosystems such as selected components of city green areas. Until now ES of the green areas in Łódź city have not been thoroughly investigated, mainly due to incomplete collection of information concerning their current state of development, especially in the oldest part of the city (downtown). Green areas of the downtown in Łódź city are mainly recreational parks, which were created simultaneously with the dynamically developing center of the 19th century industrial Łódź city. 
The aim of the paper is to define the profile of ES of recreational parks located in the downtown of Łódź city and answer the question: what ecosystem services are currently offered to residents of the city?

\section{The study area}

The study area is situated in downtown of Łódź city, the oldest city part established in its present form in 19th century. There are nine major green areas (recreational public parks): Źródliska I Park (Z1), Moniuszko Park (M), Sienkiewicz Park (Si), Staszic Park (St), Poniatowski Park (P), Reymont Park (R), Źródliska II Park (Z2), Kiliński Park (K), and Staromiejski Park (Stm) (Fig. 1). They pose the largest component of downtown green areas in Łódź $(78.3 \%)$ with the total area of 95.9 ha (Table 1$)$.

\section{Materials and methods}

The materials consist of reports of author's own field studies (eco-urban inventory) and cameral studies (ecourban documentation and spatial and functional analyzes) of Łódź green areas (2016/2017). The methods involve review of scientific literature on ecosystem services, analysis of previous data regarding eco-urban characteristics of green infrastructure of Łódź city (Długoński \& Szumański, 2016a), and identification of ecosystem services. On the basis of TEEB (TEEB, 2010, 2012) classification of ecosystem types author elaborated own classification scheme related to park ecosystems and used it in the present study.

\section{Results and Discussion}

The research on downtown parks ES in Łódź city was conducted in 2016 and in first quarter of 2017. As mentioned

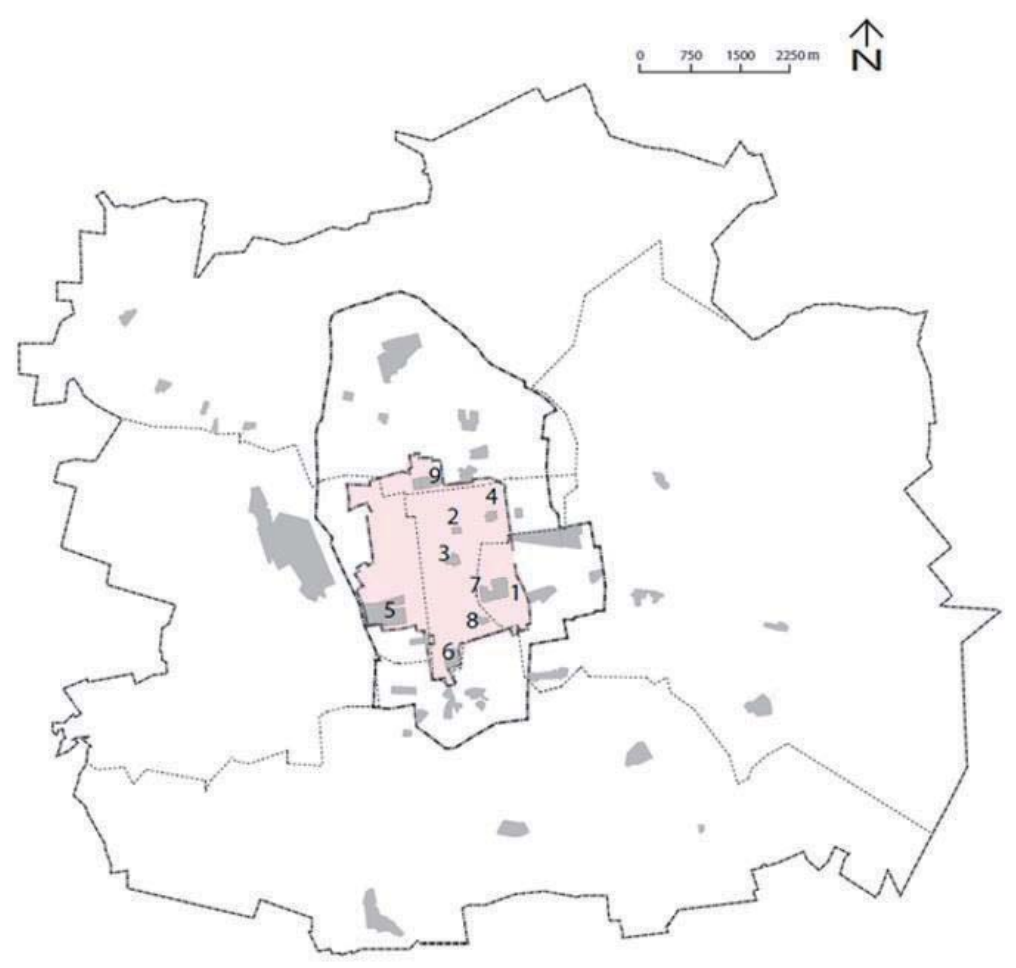

Figure1. Location of recreational parks in the downtown of Łódź city, Poland (own elaboration based on: Długoński \& Szumański 2016a). Legend: thick dashed lines - boundaries of urban zones, thin dashed lines - boundaries of districts, purple colour - downtown, gray colour - green areas, 1-9 numbers of recreational parks in downtown: 1 - Źródliska I Park (Z1), 2 - Moniuszko Park (M), 3 - Sienkiewicz Park (Si), 4 - Staszic Park (St), 5 - Poniatowski Park (P), 6 - Reymont Park (R), 7 - Źródliska II Park (Z2), 8 - Kiliński Park (K), 9 - Staromiejski Park (Stm) 
Table 1. Recreational parks of downtown in Łódź city, Poland

\begin{tabular}{|c|l|c|c|}
\hline No. & \multicolumn{1}{|c|}{ Park name (symbol) } & Park area (ha) & Number of trees (pc.) \\
\hline 1 & Źródliska I Park & 10.6 & 965 \\
\hline 2 & Moniuszko Park & 2.3 & 464 \\
\hline 3 & Sienkiewicz Park & 4.6 & 504 \\
\hline 4 & Staszic Park & 3.9 & 4124 \\
\hline 5 & Poniatowski Park & 41.7 & 562 \\
\hline 6 & Reymont Park & 6.3 & 579 \\
\hline 7 & Źródliska II Park & 6.6 & 349 \\
\hline 8 & Kiliński Park & 2.9 & 940 \\
\hline 9 & Staromiejski Park & 17.0 & 8736 \\
\hline & & 95.9 & \\
\hline
\end{tabular}

* Numbered as in Figure 1.

in Methods, own classification scheme, which seems to be appropriate to recreation parks, was applied. Ecosystem services were divided into 5 types and 19 subtypes and according to these criteria, ES in individual objects were determined and presented in Table 2.

As seen in Table 2, only three of the used criteria are fulfilled by all parks, namely walking and contemplation (recreational services), habitats for animal species (habitat services) and $\mathrm{CO}_{2}$ absorption and $\mathrm{O}_{2}$ production (regulatory services).

All nine downtown recreational parks fulfill four of five ES types. These are recreational services (walking and contemplation), habitat services (habitats for animal species), regulatory services $\left(\mathrm{CO}_{2}\right.$ absorption and $\mathrm{O}_{2}$ production), and supplying services. The maximum number of ES (five of ES types and seventeen of ES subtypes) offers the biggest Łódź' downtown green area, Poniatowski Park (P), whereas the smallest - Moniuszko Park (M) offers the fewest ES (three of ES types, and three of ES subtypes), which are: recreational services (walking and contemplation), habitat services (habitats for animal species), and regulatory services $\left(\mathrm{CO}_{2}\right.$ absorption and $\mathrm{O}_{2}$ production). Three parks: Źródliska I (Z1), Poniatowski Park (P), Staromiejski (Stm) fulfill most of the recreational, cultural, habitat, regulatory and supplying services. Firstly, in these areas recreational (basic) services are not only walking and contemplation, but also leisure on the park' grasslands open spaces (around the trees and shrubs), children's play and games (in playgrounds). Secondly, cultural services are concerts and festivals (during spring and summer season), aesthetic experiences (e.g. picturesque landscape), outside competitions (chess games), web surfing
(Internet), sports exercises (dumping and cycling in ground skatepark or physical exercises in gym or street workout). Thirdly, habitat services are not only habitats for animal species, but also species biodiversity (insects, birds, mammals etc.). Moreover, regulatory services are not only $\mathrm{CO}_{2}$ absorption and $\mathrm{O}_{2}$ production, but also air purification thanks to park' so-called buffer zone consist of trees and shrubs groups with abilities to phytoremediation purposes. Only one park - Moniuszko Park (M) does not fulfill any of cultural services and supplying services.

What is worth noting, the analyses of the results presented in Table 2 show that downtown parks potential is not fully utilized, particularly in regulatory and supplying services. In the case there are mainly shortages in wastewater treatment (lack of ponds collecting rainwater with selected plants for bioremediation purposes), as well as, biowaste management services (lack of proper bio-waste management i.e. plants incinerators or plants biogas inside the park for energy production) (Długoński \& Szumański, 2016b). There is also lack of some cultural services (extreme sports and cycling services, concert festival and didactics) in some parks. According to the field study (2016/2017) it is due to their small area or lack of revitalization (Długoński, 2017). Nevertheless, the planned revitalization of these parks may lead to the extension of the scope of these sub-types of ES in the future.

Finally, this study shows that an increase in the range of ES of downtown recreational parks in Łódź city should be thoroughly considered. The good opportunity to start this new venture is planned revitalization of Łódź downtown defined in revitalization program of Łódź city (Gminny Program Rewitalizacji Łodzi 2026+, 2016). In the con- 
Table 2. Ecosystem services (ES) types and subtypes in recreational parks in downtown of Łódź, Poland

\begin{tabular}{|c|c|c|c|c|c|c|c|c|c|}
\hline \multirow{2}{*}{$\begin{array}{l}\text { Park' number } \\
\text { and symbol }\end{array}$} & 1 & 2 & 3 & 4 & 5 & 6 & 7 & 8 & 9 \\
\hline & $\mathbf{Z 1}$ & $\mathbf{M}$ & Si & St & $\mathbf{P}$ & $\mathbf{R}$ & $\mathbf{Z 2}$ & $\mathbf{K}$ & Stm \\
\hline \multicolumn{10}{|c|}{ ES types and subtypes } \\
\hline \multicolumn{10}{|c|}{ I. Recreational (basic) services } \\
\hline walking and contemplation & $\mathrm{X}$ & $\mathrm{x}$ & $\mathrm{x}$ & $\mathrm{x}$ & $\mathrm{x}$ & $\mathrm{x}$ & $\mathrm{x}$ & $\mathrm{x}$ & $\mathrm{x}$ \\
\hline leisure on grasslands & $\mathrm{X}$ & & & & $\mathrm{x}$ & & & & \\
\hline children's play and games & $\mathrm{X}$ & & $\mathrm{x}$ & $\mathrm{x}$ & $\mathrm{x}$ & $\mathrm{x}$ & & & $\mathrm{x}$ \\
\hline TOTAL & 3 & 1 & 2 & 2 & 3 & 2 & 1 & 1 & 2 \\
\hline \multicolumn{10}{|c|}{ II. Cultural services } \\
\hline concerts and festivals & $\mathrm{X}$ & & & & $\mathrm{x}$ & & & & $\mathrm{x}$ \\
\hline school didactic & $\mathrm{X}$ & & & $\mathrm{x}$ & $\mathrm{x}$ & & & & \\
\hline aesthetic experiences & $\mathrm{X}$ & & $\mathrm{x}$ & $\mathrm{x}$ & $\mathrm{x}$ & $\mathrm{x}$ & $\mathrm{x}$ & & $\mathrm{x}$ \\
\hline competitions (chess) & $\mathrm{X}$ & & & & $\mathrm{x}$ & $\mathrm{x}$ & & & $\mathrm{x}$ \\
\hline web surfing & $\mathrm{X}$ & & $\mathrm{x}$ & $\mathrm{x}$ & $\mathrm{x}$ & $\mathrm{x}$ & $\mathrm{x}$ & & $\mathrm{x}$ \\
\hline sports excercies & $\mathrm{X}$ & & $\mathrm{x}$ & $\mathrm{x}$ & $\mathrm{x}$ & $\mathrm{x}$ & & $\mathrm{x}$ & $\mathrm{x}$ \\
\hline cycling & & & & & $\mathrm{x}$ & & & & \\
\hline extreme sports (hillride) & & & & & $\mathrm{x}$ & & & & \\
\hline spiritual experiences & & & & & $\mathrm{x}$ & & & & $\mathrm{x}$ \\
\hline TOTAL & 6 & 0 & 3 & 4 & 9 & 4 & 2 & 1 & 6 \\
\hline \multicolumn{10}{|c|}{ III. Habitat services } \\
\hline habitats for animal species & $\mathrm{X}$ & $\mathrm{x}$ & $\mathrm{x}$ & $\mathrm{x}$ & $\mathrm{x}$ & $\mathrm{x}$ & $\mathrm{x}$ & $\mathrm{x}$ & $\mathrm{x}$ \\
\hline biodiversity & $\mathrm{X}$ & & $\mathrm{x}$ & $\mathrm{x}$ & $\mathrm{x}$ & & $\mathrm{x}$ & & $\mathrm{x}$ \\
\hline TOTAL & 2 & 1 & 2 & 2 & 2 & 1 & 2 & 1 & 2 \\
\hline \multicolumn{10}{|c|}{ IV. Regulatory services } \\
\hline wastewater treatment & & & & & & & $\mathrm{x}$ & & \\
\hline air purification & $\mathrm{X}$ & & & $\mathrm{x}$ & $\mathrm{x}$ & & $\mathrm{x}$ & & $\mathrm{x}$ \\
\hline $\mathrm{CO}_{2}$ absorption and $\mathrm{O}_{2}$ production & $\mathrm{X}$ & $\mathrm{x}$ & $\mathrm{x}$ & $\mathrm{x}$ & $\mathrm{x}$ & $\mathrm{x}$ & $\mathrm{x}$ & $\mathrm{x}$ & $\mathrm{x}$ \\
\hline TOTAL & 2 & 1 & 1 & 2 & 2 & 1 & 3 & 1 & 2 \\
\hline \multicolumn{10}{|c|}{ V. Supplying services } \\
\hline rainwater collection & $\mathrm{X}$ & & & $\mathrm{x}$ & $\mathrm{x}$ & $\mathrm{x}$ & $\mathrm{x}$ & & $\mathrm{x}$ \\
\hline \multicolumn{10}{|l|}{ biowaste management* } \\
\hline TOTAL & 1 & 0 & 0 & 1 & 1 & 1 & 1 & 0 & 1 \\
\hline TOTAL ES (subtypes) & $5(14)$ & $3(3)$ & $4(8)$ & $5(11)$ & $5(17)$ & $5(9)$ & $5(9)$ & $4(4)$ & $5(13)$ \\
\hline
\end{tabular}

Legend: 1 - Źródliska Park I (Z1), 2 - Moniuszko Park (M), 3 - Sienkiewicz Park (Si), 4 - Staszic Park (St), 5 - Poniatowski Park (P), 6 - Reymont Park (R), 7 - Źródliska II Park (Z2), 8 - Kilińnki Park (K), 9 - Staromiejski Park (Stm). 
text of downtown recreational parks a particular attention should be paid to their significant potential of delivering any supplying services (use of rain waters and park biowaste for energy production) and regulatory services (plant treatment).

\section{Conclusions}

The selected in this paper materials and methods, as well as, field and cameral studies of downtown green areas in Łódź city helped to define ES types and sub-types in these sites. The conducted study may serve as a basis for further research on the evaluation of ecosystem services in parks, as well as other case studies of green areas in cities.

\section{References}

Baur J.W.R., Tynon J.F., Ries P. \& Rosenberger S.A., 2014, Urban Parks and Attitudes about Ecosystem Services: Does Park Use Matter? Journal of Park and Recreation Administration 32(4): 19-34.

Costanza R., d'Arge R., de Groot R., Farber S., Grasso M., Hannon B., Limburg K., Naeem S., O’Neill R.V., Paruelo J., Raskin R.G., Sutton P \& van den Belt M., 1997, The value of the world's ecosystem services and natural capital. Nature 387: 253-260.

Czembrowski P. \& Kronenberg J., 2016, Hedonic pricing and different urban green space types and sizes: Insights into the discussion on valuing ecosystem services. Landscape and Urban Planning 146/2016: 11-19. (http://dx.doi.org/10.1016/j.landurbplan.2015.10.005).

Deptuła M., 2014, Ecosystem services of Kampinos National Park for the city of Warsaw. EUROPA XXI. Institute of Geography and Spacial Organization Polish Academy od Sciences 27: 19-31. (http://dx.doi. org/10.7163./Eu21.2014.27.2).

Długoński A., 2017, Wpływ procesu rewitalizacji terenów zieleni na zdrowie mieszkańców miast (studium przypadku - centrum miasta Łodzi) [The impact of the revitalization of green areas on the health of urban residents (case study - city center of Łódź)], [in:] Gospodarka przestrzenna, stan obecny i wyzwania przyszłości ujęcie interdyscyplinarne, Konferencja naukowa, Abstrakty [Land management: current status and future challenges - an interdisciplinary approach, Scientific conference, Book of abstracts], 25-26.09.2017. Uniwersytet Przyrodniczy we Wrocławiu, Wydział Inżynierii Kształtowania Środowiska i Geodezji, Katedra Gospodarki Przestrzennej, Wrocław: 13-14.

Długoński A. \& Szumański M., 2016a, Atlas ekourbanistyczny zielonej infrastruktury miasta Łodzi, Tom I. Tereny zieleni, Teka 1a. Parki strefy śródmiejskiej
[Eco-Urban Atlas of Green Infrastructure of Łódź City, Poland. Green Areas in Łódź City Parks in Urban Zone], Łódzkie Towarzystwo Naukowe, Łódź.

Długoński A. \& Szumański M., 2016b, Use of recreational park bio-waste as locally available energy resource. Ecological Chemistry and Engineering (A) 3/2016: 265-274.

Gminny Program Rewitalizacji Łodzi 2026+, 2016, [The Commune Revitalization Program of Łódź 2026]. Urząd Miasta Łodzi [The Office of Lodz city], Łódź.

Haase D., Larondelle N., Andersson E., Artmann M., Borgström S., Breuste J., Gomez-Baggethun E., Gren Å., Hamstead Z., Hansen R., Kabisch N., Kremer P., Langemeyer J., Rall E.L., McPhearson T., Pauleit S., Qureshi S., Schwarz N., Voigt A., Wurster D. \& Elmqvist T., 2014, A quantitative review of urban ecosystem service assessments: concepts, models, and implementation. Ambio 43(4): 413-433. [DOI: 10.1007/ s13280-014-0504-0].

Kabisch N., Strohbach M., Haase D. \& Kronenberg J., 2016, Urban green space availability in European cities. Ecological Indicators 70: 586-596. (http://dx.doi. org/10.1016/j.ecolind.2016.02.029).

Kronenberg J., \& Hubacek K., 2016, From poverty trap to ecosystem service curse. Sustain Sci. 11/2016: 903907. [DOI 10.1007/s11625-016-0370-8].

Millennium Ecosystem Assessment, 2005, Ecosystems and Human Well-being: Synthesis. Island Press, Washington, DC.

Singh R. \& Singh G.S., 2017, Ecosystem services: A bridging concept of ecology and economics. Ecological Questions 25: 95-101.

Speak A.F., Mizgajski A. \& Borysiak J., 2015, Allotment gardens and parks: Provision of ecosystem services with an emphasis on biodiversity. Urban Forestry \& Urban Greening 14: 772-781. (http://dx.doi.org/10.1016/j. ufug.2015.07.007).

Szulczewska B., 2014, W pułapkach zielonej infrastruktury [Trapped green infrastructure], [in:] A. Pancewicz (ed.), Zielona infrastruktura miasta [Green infrastructure of the city]. Wyd. Politechniki Śląskiej, Gliwice: 9-29.

TEEB, 2010, The Economics of Ecosystems and Biodiversity: Ecological and Economic Foundations. Earthscan, London Washington.

TEEB, 2012, Poradnik TEEB dla miast: usługi ekosystemów w gospodarce miejskiej [TEEB Guide for Cities: Ecosystem Services in Urban Economy]. Fundacja Sendzimira, Kraków.

Żylicz T., 2015, An economist looks at ecosystem services, [in:] M. Burchard-Dziubińska (ed.), Towards a green economy. From ideas to practice.Wyd. Uniwersytetu Łódzkiego, Łódź: 11-29. 